Please cite this article as:

Kovač-Andrić Elvira, Gvozdić Vlatka, Herjavić Glenda and Muharemović Hasan, Assessment of ozone variations and meteorological influences in a tourist and health resort area on the island of Mali Lošinj (Croatia). Environmental Science and Pollution Research, 2013, 20 (8): 5106-5113. doi: 10.1007/s11356-013-1484-5

The final publication of this article is available at link.springer.com (http://rd.springer.com/article/10.1007/s11356-013-1484-5).

Published online: 22 January 2013

\title{
Assessment of ozone variations and meteorological influences in a tourist and health resort area on the island of Mali Lošinj (Croatia)
}

Elvira Kovač-Andrić ${ }^{1 *}$, Vlatka Gvozdić ${ }^{2}$, Glenda Herjavić ${ }^{3}$ and Hasan Muharemović ${ }^{3}$

(1) Department of Chemistry, University of J. J. Strossmayer, Franje Kuhača 20, 31000

Osijek, Croatia

(2) Department of Chemistry, University of J. J. Strossmayer, Franje Kuhača 20, 31000

Osijek, Croatia

(3) Institute "Ruđer Bošković", Bijenička cesta 54, 10000 Zagreb, Croatia

*Corresponding author: Elvira Kovač-Andrić, e-mail: eakovac@kemija.unios.hr

\begin{abstract}
The purpose of this study was to investigate ozone, variations, and its correlation with meteorological parameters at a remote location on the Mali Lošinj Island, which has been a tourist and health resort area in the northern Adriatic. The measured data are discussed in relation to the EU guidelines (Directive 2002/3/EC; Directive 2008/50/EC). In order to characterize ambient air with respect to ozone vegetation injury and photochemical pollution, we calculated accumulated dose over a threshold of 40 parts per billion index and two photochemical pollution indicators. The influence of local meteorological parameters on the measured ozone volume fractions was also investigated. We used the multivariate technique principal component analysis to trace correlations between measured ozone concentration and meteorological parameters.
\end{abstract}

Keywords: AOT40 index, Frequency analysis, Mali Lošinj, Mediterranean, Ozone, PCA, Photochemical pollution indicators, Vegetation injury

\section{Introduction}

In Croatia, heliomarinotherapy is practiced on the island of Lošinj located in the south of the Kvarner Bay (Northern Adriatic Coast). Although the main indication for heliomarinetherapy is psoriasis, this therapeutic option has also been used for treating atopic dermatitis and vitiligo; theoretically, it could be adapted to treat the pruritus from renal failure and human immunodeficiency virus (Stasić et al. 2004; Even-Paz and Efron 2003; Moosa and Esterhyse 2010). The therapeutic efficiency of heliomarinotherapy may be influenced by various climatic and meteorological factors, seasonal variations of tropospheric ozone, as well as by their mutual dependences on meteorological factors (Even-Paz and Efron 2003). Despite of its great influence on human activities and health, ozone in this part of Northern Adriatic is not 
sufficiently researched and analyzed, especially concerning the meteorological basis of its 24hourly variations.

At ground level in the atmospheric boundary layer, ozone is an important oxidant. It is formed in air by photochemical reactions of precursor pollutants such as $\mathrm{NO}_{\mathrm{x}}$ and volatile organic compounds (VOCs). In the Mediterranean, the summer months are of highest interest due to favorable meteorological conditions, high insolation, as well as anthropogenic and biogenic ozone precursors concentrations that favor photochemical ozone production (Dueñas et al. 2002; Paoletti 2009; Kalabokas et al. 2007, 2008; Sánchez et al. 2008; Schürmann et al. 2009; Notario et al. 2012).

Exposure to pollutants, in particular to ozone and particulate matter, leads to adverse health effects such as asthma, bronchitis, heart attack, and other cardiopulmonary problems and even premature death (Kunst et al. 1999; Stedman 2004; Chen et al. 2010). The target value for the protection of human health is $120 \mu \mathrm{g} / \mathrm{m}^{3}$ (8-h running averages) that may not be exceeded on more than 25 days per calendar year averaged over 3 years, which is in use in European countries. (Directive 2002/3/E; Directive 2008/50/EC).

Among many environmental effects, ozone also affects vegetation. The damage considered significant here includes growth changes, yield losses, visible injury, and reduced seed production and quality (Bytnerowicz et al. 2007; Ashmore 2005; Cape 2008; Wittig et al. 2009). Risks for agricultural and horticultural crops and forests are currently evaluated in Europe with the exposure index accumulated dose over a threshold of 40 parts per billion (ppb) (AOT40), i.e., the sum of the difference between hourly concentrations greater than $80 \mu \mathrm{g} / \mathrm{m}^{3}(=40 \mathrm{ppb})$ and $80 \mu \mathrm{g} / \mathrm{m}^{3}$ over a given period during daylight hours (Directive 2002/3/EC; Directive 2008/50/EC; Ferretti et al. 2007). An AOT40 of 20,000 $\left(\mu \mathrm{g} / \mathrm{m}^{3}\right) \times$ hours for daylight hours (from 08:00 to 20:00 CET), accumulated over a 6-month growing season (April to September), was proposed as a critical level to protect forest trees. For the protection of vegetation, the critical value for AOT40, accumulated over a 3-month growing season (May-July), is $18,000\left(\mu \mathrm{g} / \mathrm{m}^{3}\right) \times$ hours averaged over 5 years with a long-term objective of $6,000\left(\mu \mathrm{g} / \mathrm{m}^{3}\right) \times$ hours (Directive 2002/3/EC; Directive 2008/50/EC). Under this perspective, the knowledge about AOT40 values is important for assessment of risk of forest and vegetation injuries due to ozone exposure.

Another approach for the assessment of ambient air quality through the monitoring of ozone is by calculating photochemical pollution indicators (Kovač-Andrić et al. 2010; Klasinc et al. 2011). These indicators use as a basic parameter the average of the daily maximum to minimum ratio of hourly ozone concentrations over a period of time corrected by taking into account either daily average of ozone and its maximum or the time a limit value has been exceeded.

Meteorology plays an important role in the formation and transport of ozone. Changes in weather conditions, i.e., light winds, high temperatures, and strong sunlight (clear sky), can affect the formation and increase in ozone volume fraction in the boundary layer. Principal component analysis (PCA) was used to identify the important factors influencing ozone concentrations, for examination of outliers, and clustering of days. Summer months are of particular interest because the arrival of a large number of tourists and an associated increase in traffic (Božić et al. 2006), which causes a substantial increase in pollution. The influence of meteorological variables on the ozone concentrations during this period is particularly wind direction.

\section{Experimental}

The town of Mali Lošinj is situated in the southern part of the island of Lošinj, in the northern Adriatic, and it is a small maritime, commercial, and tourist center. The climate is 
Mediterranean, with average summer temperatures of $24^{\circ} \mathrm{C}$ and winter of $11.7{ }^{\circ} \mathrm{C}$. With over $2,600 \mathrm{~h}$ of sunshine per year, or an average of about $7 \mathrm{~h}$ a day, Mali Lošinj is one of the sunniest places in Croatia.

Measurements of ozone concentration were carried out during the spring, summer, and autumn months of 2005 at Mali Lošinj $\left(44.53^{\circ} \mathrm{N} 14.46^{\circ} \mathrm{E}, 43 \mathrm{~m}\right.$ a.s.l.) (see Fig. 1 ). The monitoring station was located away from major pollution sources. The closest emission sources are Pula (air distance $63 \mathrm{~km}$ ), Zadar (air distance $79 \mathrm{~km}$ ), and the highly industrialized town of Rijeka (air distance $85 \mathrm{~km}$ ). There are no significant pollution sources on the island itself except increased traffic during the tourist season. The monitoring period was from April 27 th 2005 to October 19th 2005. We achieved $100 \%$ coverage of data for the vegetation growing season (May-July) and $85.2 \%$ coverage of data for the 6-month growing season (April-September) as we started the measuring campaign at the end of April. Ozone has been monitored with a commercial UV photometer Ansyco O341M (Environnement S.A.). The equipment has regularly maintained and calibrated.

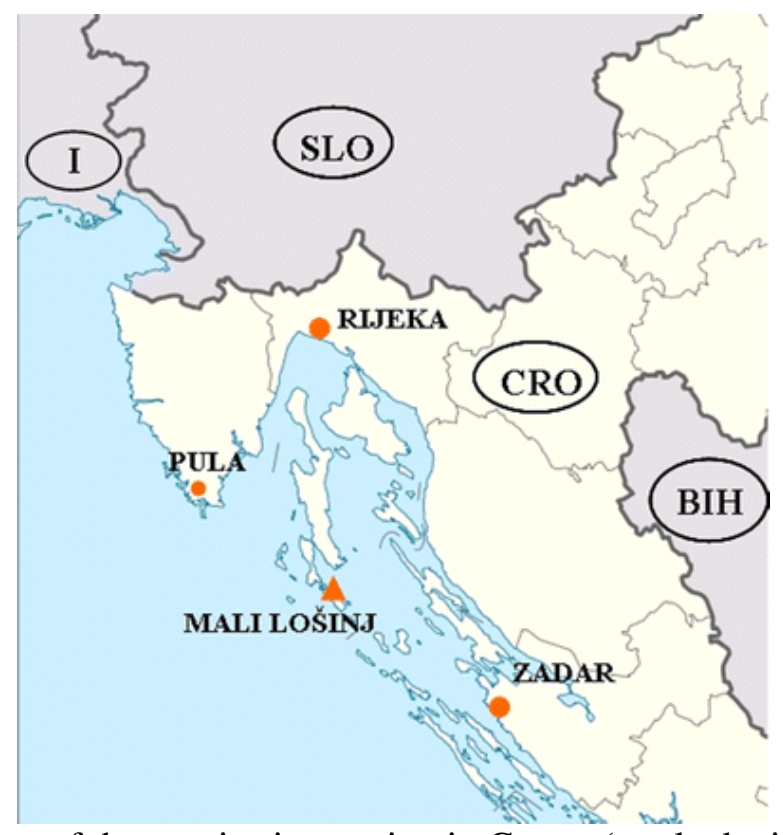

Fig. 1 Location of the monitoring station in Croata (marked with a triangle).

Meteorological data were obtained from the Meteorological and Hydrological Service of Croatia. Monitored meteorological parameters were solar radiation time (Sun, expressed in hours), temperature ( $\mathrm{t}$ expressed in degrees Celsius), relative humidity ( $\mathrm{Rh}$, expressed in percent), cloudiness (Clo, expressed in percent), visibility (Vis, expressed in kilometers), wind speed (WS, expressed in kilometres per hour), precipitation (Pr, expressed in millimeter), and pressure (p, expressed in hectopascal).

\section{Results and discussion}

Based on the 1-min values obtained from the instrument, we calculated hourly mean values, diurnal distribution of ozone volume fractions, and the eight hours running averages.

Variation of ozone in relation with meteorological parameters has been analyzed, and photochemical pollution indicators and an AOT40 exposure index were also calculated. The PCA method has also been used to investigate relationships between ozone volume fractions and meteorological variables. 


\section{Daily and seasonal ozone variations and frequency analysis}

This section describes the daily distribution of ozone volume fractions, seasonal cycles, and frequency analysis of ozone data for the monitoring period. The box and whiskers plot in Fig. 2 summarizes the hourly ozone volume fractions for the measuring period at Mali Lošinj. The daily range of variation during the spring and summer are more marked than in autumn, when the range is smaller. Concentrations decline from a peak in the spring to a minimum during the autumn, which is typical of a Northern Hemisphere rural site. During spring and summer periods are pronounced diurnal cycle with low levels of ozone in the early morning, minimum around 7ロ am local time, and peak concentrations in the afternoon, from 12 to $16 \square \mathrm{pm}$ local time. This pattern is likely to be attributed almost exclusively to physical processes as the influence of chemistry in this nonindustrial and health resort area is expected to be minimal. The ozone levels tended to follow the daily cycles of temperature and solar radiation intensity, resulting in higher ozone levels during the daylight hours. The information $\left(180 \mu \mathrm{g} \square \mathrm{m}^{-3}\right)$ and alert $\left(240 \mu \mathrm{g} \square \mathrm{m}^{-3}\right)$ threshold value of the 98th percentile values for hourly averages as established in European Union legislation to protect human health were not exceeded once throughout the measurement period. Regarding the protection of human health, there were only 9.6 days exceeding the $60 \mathrm{ppb}$ threshold versus the 25 days per calendar year as established in the EU Directive and also in Croatian law for ozone pollution in ambient air. Since higher concentrations of ozone are expected in spring and summer months, we do not expect that this value at Mali Lošinj might be exceeded if we take into account the entire year. For comparison, due to long warm summer, at some locations in the nearby Rijeka Bay, the number of days exceeding the running 8-h target value for human health protection in 2005 were considerably higher (as much as 130 days) (Alebić-Juretić 2011).

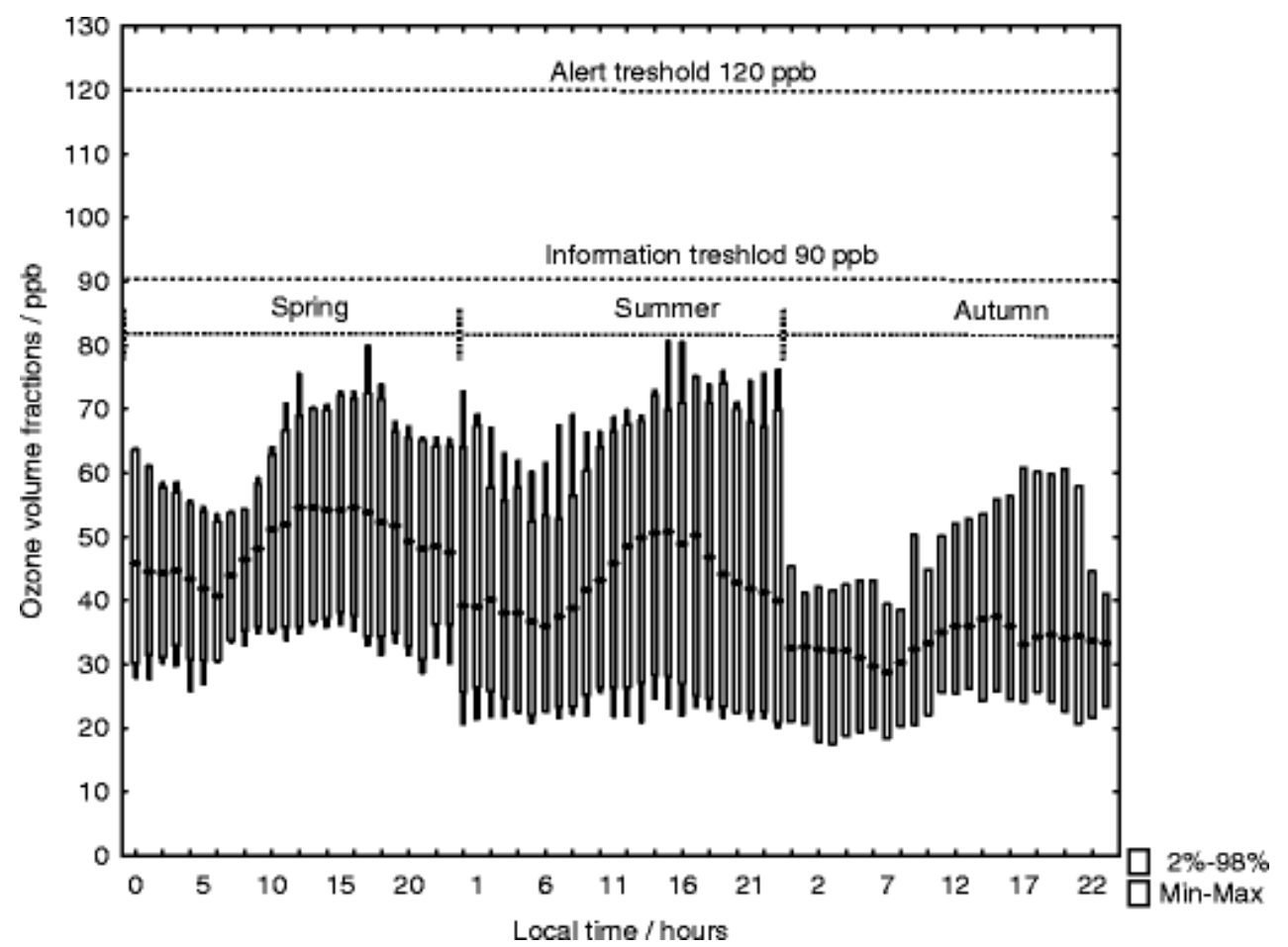

Fig. 2 Box and whiskers plot of the hourly ozone volume fractions for the period April 27 to October 19, 2005 at Mali Lošinj.

It is well known that this coastal site is highly visited in summer months being an important medical and touristic destination, so ozone concentrations can be influenced by human activities. There is no known natural or meteorological mechanism that creates climate cycles 
with weekly periodicity, but such cycles have been shown to exist in and around centers of urbanization and have been generally attributed to anthropogenic activities (Shuters and Balling Jr. 2006; Klasinc et al. 2008; Cvitaš et al. 2004; Kovač-Andrić et al. 2009; Gvozdić et al. 2011). To investigate the occurrence of possible ozone "weekend effect" at the site, we examined the weekly cycles of hourly averaged ozone concentrations. The timing of maximum and minimum ozone concentrations did not vary between weekend and weekdays. Maximum ozone concentrations were observed around 15-16 $\square \mathrm{pm}$ and minimum between 6 and $8 \square$ am both on weekend and weekdays. In Fig. $\underline{3}$, we observed differences of only $1-$ $3 \mathrm{ppb}$ in ozone volume fractions for weekdays and weekend days. Applying criteria by Blanchard and Fairley (Adame et al. 2008), which propose that the weekend effect is generally statistically significant if the ozone concentration difference exceeds $10 \mu \mathrm{g} \square \mathrm{m}^{-3}$ $(\approx 5 \mathrm{ppb})$, we conclude that Mali Lošinj does not show a weekend effect, but it still indicates that the weekend values are higher, which somewhat expected at rural sites with some influence from traffic due to titration of ozone from $\mathrm{NO}_{\mathrm{x}}$ due to car exhausts (Kley et al. 1994).

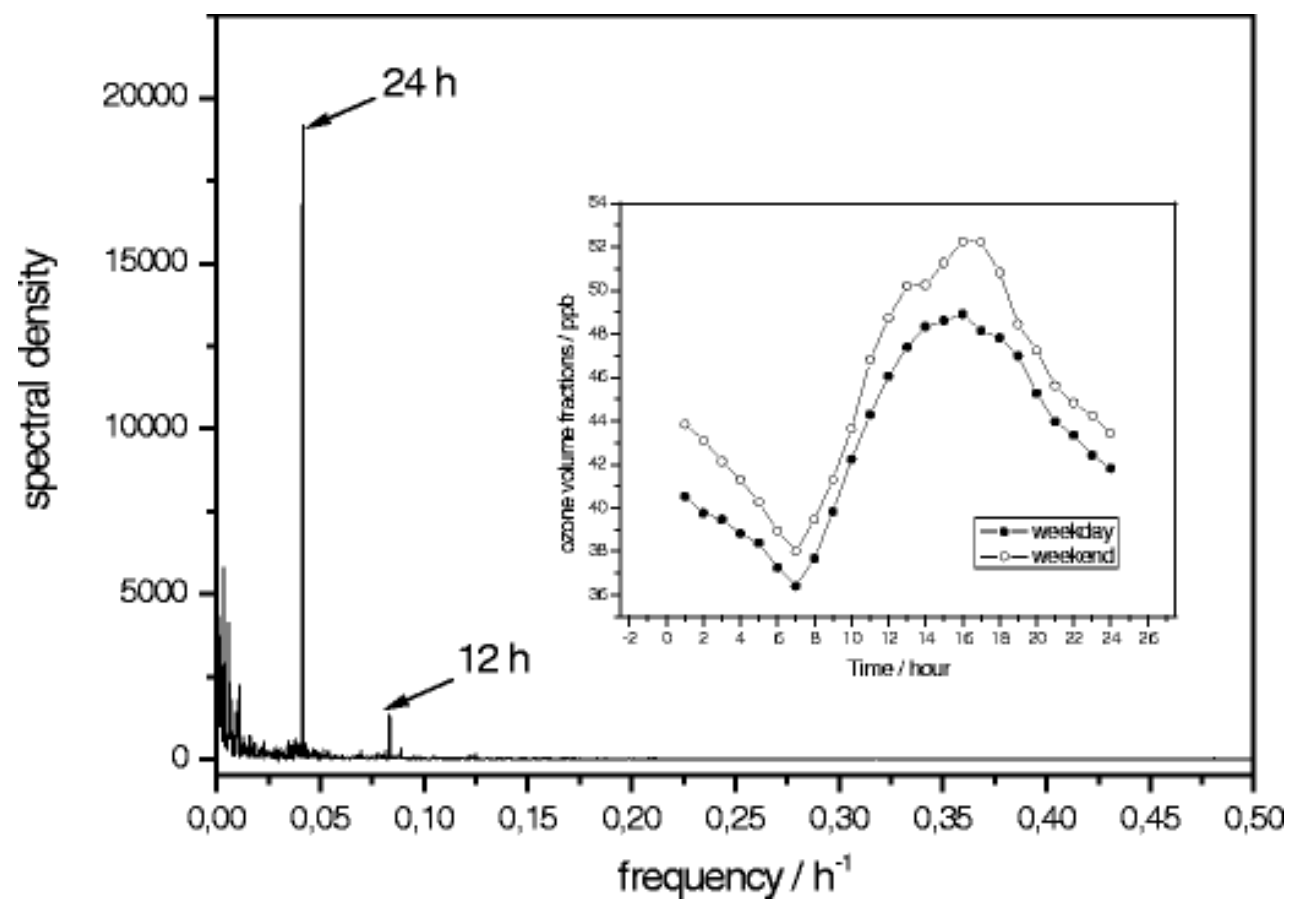

Fig. 3 The Fourier transformation of $\mathrm{O}_{3}$ data and average hourly ozone volume fractions for weekdays and weekends for the measurement period at the site of Mali Lošinj. The number of hours corresponding to the statistically significant frequency peaks is denoted by an arrow

Nevertheless, in order to investigate existence of possible significant periodicities in the time series of ozone data, we calculated their Fourier spectra for the whole measurement period. Fourier analysis confirms the existence of variation in ozone volume fractions periods such as usual daily cycle, but a statistically significant frequency peak for a 7-day cycle was not observed. The occurrence of the weekend effect is usually observed at highly polluted sites, where emission changes have an immediate and detectable influence on photochemistry. However, this phenomenon is often attenuated if there are other factors contributing to the ozone formation, for example, in coastal areas the influence of coastal breezes. Therefore, local atmospheric mechanisms may affect the ozone levels more strongly than possible changes in the emissions of precursors according to the weekday (Adame et al. $\underline{2008}$ ). 


\section{AOT40 index and photochemical pollution indicators}

For the calculation of AOT40 values, we used hourly mean values above $40 \mathrm{ppb}\left(80 \mu \mathrm{g} / \mathrm{m}^{3}\right)$ of $12 \mathrm{~h}$ daylight period (0800 to 2000 CET) between May-July and April-September. There were 1,472 $\mathrm{h}$ for the period of April-September and 1,008 $\mathrm{h}$ for the period May-July above the threshold of $40 \mathrm{ppb}$. We also calculated AOT40 estimate because there were no available data for all days for April 2005 (see Table 1). Total possible number of hours (the number of hours within the time period of AOT40 definition) for the period 1 April-30 September (0800 to 2000 CET) is $2,196 \mathrm{~h}$.

Table 1 Data coverage, AOT40 measured, and AOT40 $_{\text {estimate }}$ for the measurements at Mali Lošinj for the period April to September 2005.

\begin{tabular}{|l|l|l|l|}
\hline Growing season & $\begin{array}{l}\text { Data coverage } \\
(\boldsymbol{\%})\end{array}$ & $\begin{array}{l}\text { AOT40 } \\
\left(\boldsymbol{\mu g} / \mathbf{m}^{3}\right) \times \text { hours }\end{array}$ & $\begin{array}{l}\text { AOT40 } \\
\left(\boldsymbol{\mu g} / \mathbf{m}^{3}\right) \times \text { hoursate }\end{array}$ \\
\hline May-July & 100 & 26,100 & - \\
\hline April-September & 85.2 & 32,067 & 37,637 \\
\hline
\end{tabular}

In the period 1 May to $31 \mathrm{July,}$ we have $100 \%$ coverage of ozone data. For the period 1 April-30 September, we have missing data, and the hourly data coverage is $85.2 \%$. Thus, we calculated AOT40 $0_{\text {estimate }}$ in regard to $100 \%$ data coverage.

AOT $40_{\text {estimate }}$ is calculated from the formula:

$$
\text { AOT } 40_{\text {estimate }}={\text { AOT } 40_{\text {measured }}} \times \frac{\text { total possible number of hours }(*)}{\text { number of measured hourly values }}
$$

All the values for AOT40, measured and estimated, exceed the critical level of $20,000\left(\mu \mathrm{g} / \mathrm{m}^{3}\right)$ $\times$ hours for the protection of forest and of $18,000\left(\mu \mathrm{g} / \mathrm{m}^{3}\right) \times$ hours for the protection of vegetation. Until today, in Croatia, there has not been any research related to the injury of forest trees on the island of Lošnj. Nevertheless, as pointed out by many authors in the literature, ozone plant injury is more closely related to dose (ozone flux through the stomata) than to external ozone exposure (Cieslik 2004; Mills et al. 2011; Baumgarten et al. 2009.) Thus, studies of damage on trees are needed to evaluate the condition of the trees and the impact of ozone on them. However, the AOT40 index indicates that there is a possibility of ozone injury on vegetation.

To characterize ambient air with respect to photochemical pollution, we also calculated two photochemical pollution indicators. These two parameters are the ozone volume fractions in excess of an hourly average of $80 \mathrm{ppb}$ as the limit value for air quality. One gives an overall total volume fraction that crossed the limit for the entire period measured, and the second is the total number of hours in which he exceeded the limit of $80 \mathrm{ppb}$. If the index value $\mathrm{P}_{1}<7$, measurement sites are considered clean due to photochemical pollution. Calculating the index $\mathrm{P}_{2}$ gives a simple option of grouping the data into three classes: pure $\left(\mathrm{P}_{2}<10\right)$, medium clear $\left(10<\mathrm{P}_{2}<40\right)$, and the contaminated area $\left(\mathrm{P}_{2}<100\right)$ (Kovač-Andrić et al. 2010; Klasinc et al. 2011). The photochemical pollution indicators for the period April-September were calculated from the formula $\mathrm{P}_{1}=\mathrm{R} * \mathrm{M} / \mathrm{A}$ and $\mathrm{P}_{2}=\mathrm{R} *\left(1+7 * \mathrm{D} / \mathrm{N}_{\mathrm{d}}\right)$, where $\mathrm{R}$ is the average maximum to minimum ratio of hourly ozone data, $\mathrm{M}$ is the average maximum value obtained as the average of daily maximum values, $\mathrm{A}$ is the average of hourly mean values, $\mathrm{D}$ is the number of hours ozone volume fractions exceeded the limit of $80 \mathrm{ppb}$, and $\mathrm{N}_{\mathrm{d}}$ is the number 
of monitoring days per monitoring period, in our case 176 days. Thus, with indicator values below 2, $\mathrm{P}_{1}=1.92$ and $\mathrm{P}_{2}=1.72$, the location of Mali Lošinj can be considered as relatively clean area with negligible local photochemical pollution.

\section{PCA and influence of meteorology}

The relationship of ozone volume fractions with winds from different sectors was studied in order to investigate the possible transport of ozone from various directions. Since ozone is generated during daylight hours, the aim of this research was to perform PCA of diurnal mean ozone concentrations only for that period, and meteorological parameters are thus calculated as the mean values for that period. Figure 4 presents the correlation between the wind directions and ozone volume fractions. It is not surprising that higher ozone concentrations arrive with southwest air masses as there is a possibility of overseas transboundary transport of pollution coming from west Mediterranean area. This finding is also consistent with the results of Prtenjak et al. (2009 who reported higher ozone concentrations in the Rijeka Bay area advected from Gulf of Trieste. The Rijeka Bay has a unique topography where airborne pollutants are not easily ventilated out of the Bay under light wind conditions. $\mathrm{O}_{3}$ originating from Gulf of Trieste is carried by the western sea breeze and then caught by the convergence zone above Istria (Prtenjak et al. 2009). However, climatological studies conducted along the Adriatic Coast from June to September showed that the strongest sea breezes $\left(5.5 \mathrm{~m} \mathrm{~s}^{-1}\right)$ are observed in Mali Lošinj, which makes this area much more ventilated and thus more comfortable and healthy for humans than the coastal region. This finding is supported by the fact that average monthly ozone concentrations in Mali Lošinj region were lower in comparison with concentrations measured at several sites of the Rijeka Bay area, in the same period (Alebić-Juretić 2011).

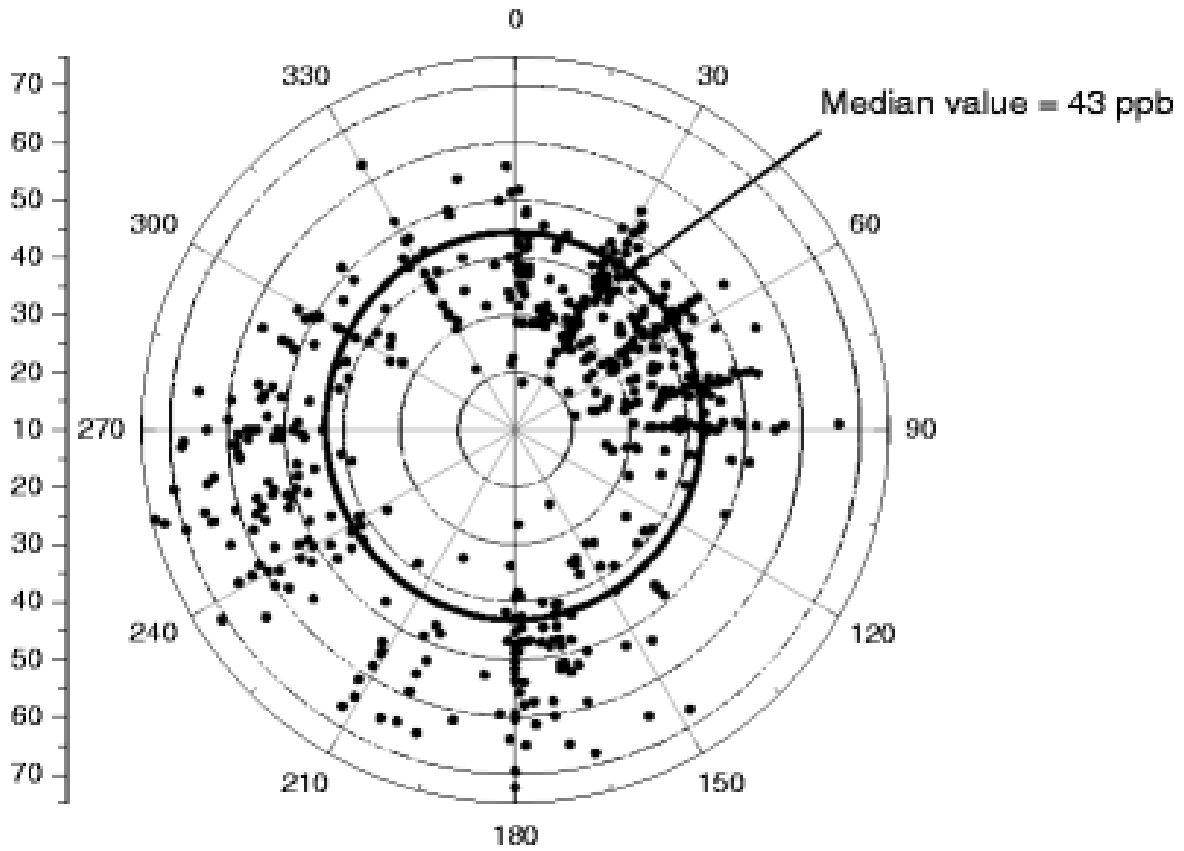

Fig. 4 Average ozone volume fractions for different wind directions at Mali Lošinj for the monitoring period April to October 2005

A good understanding of the connection between meteorology and ozone concentrations is needed to evaluate the likely effects of climatic changes on ozone concentrations. PCA has 
been successfully applied to identify the dominant relationships presented in measured data (Statheropoulos et al. 1998).

To investigate the influence of meteorological parameters on ozone volume fractions, a PCA model has been developed (Lengyel et al. 2004; Abdul-Wahab et al. 2005; Kovač-Andrić et al. 2009; Gvozdić et al. 2011). PCA, followed by varimax rotation, yields the results given in Fig. $\underline{5}$ for the loadings and scores (i.e., biplot). It provides an overview of interrelationships between monitored meteorological parameters and collected air samples. The model developed for both the ozone and meteorological variables showed that ozone is highly correlated with temperature, pressure, solar radiation time, and visibility. Ozone concentrations are highly influenced by temperature and sun radiation time, which reflects the importance of photochemistry for ozone formation. It is known that Mediterranean summers, connected with high pressure systems leading to subsidence, stability, clear skies, and high sun intensity, enhance photochemical processes and emissions of biogenic volatile organic compounds to the atmosphere (Kalabokas and Repapis 2004; Velchev et al. 2011).

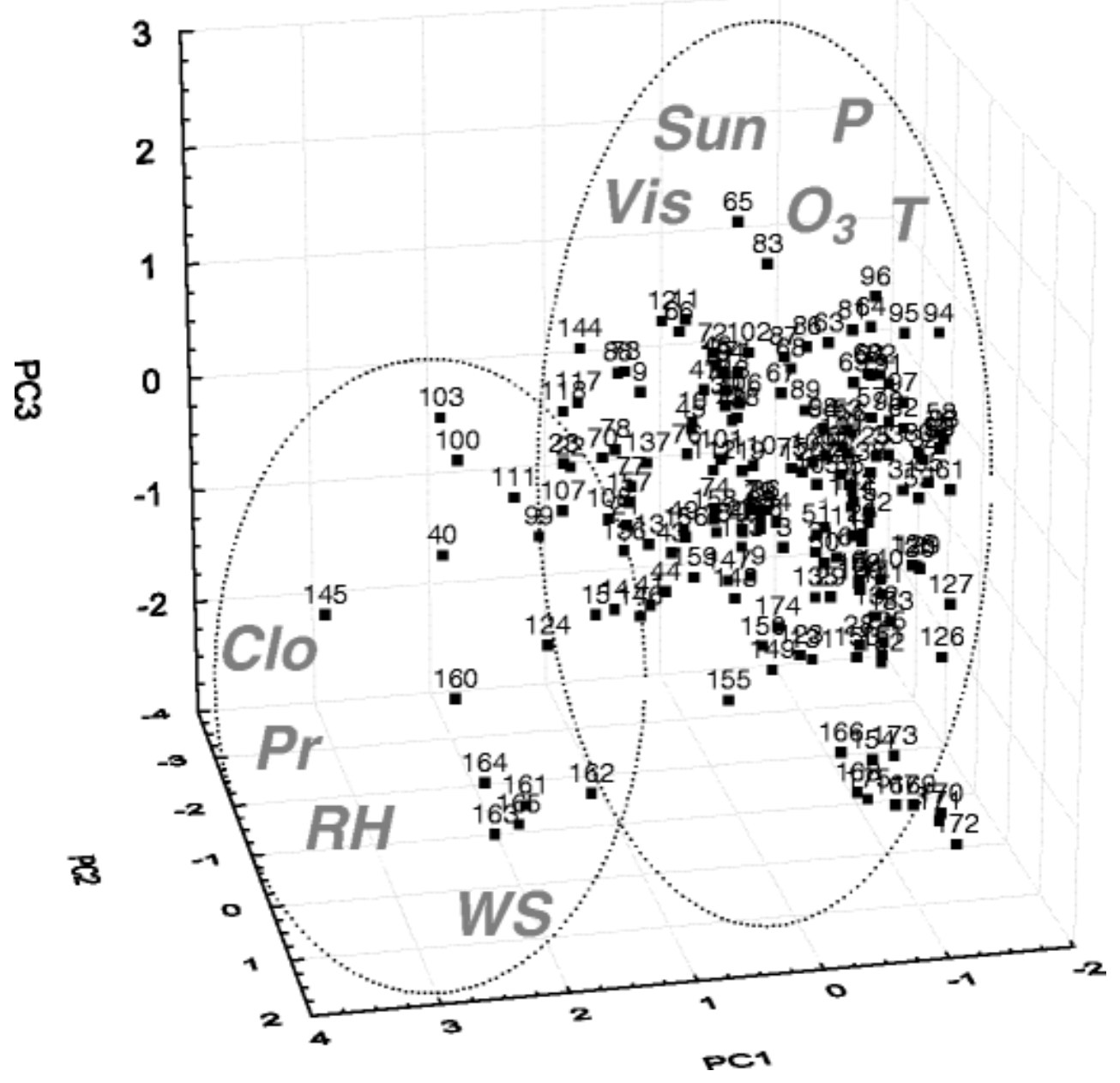

Fig. 5 3D plot of score and loadings (biplot)

Furthermore, analysis of these data for summer showed wind speed does have no effect on ozone formation, whereas relative humidity, cloud cover, and rainfall were strongly negatively correlated to $\mathrm{O}_{3}$. Higher relative humidity and wet weather are usually associated with lower ozone concentrations due to reduction of photochemical activities, but the main factor that decreases ozone concentration is reduction in radiation and temperature. Besides, 
ambient humidity affects minimum temperature via absorption of long-wave radiation by the Earth that would otherwise, under dry conditions, be lost in space and via the release of the latent heat of condensation as the sensible temperature falls to dew point (Banja et al. 2012).

The biplot can be used for the determination of the contribution of the various sources of variances (PCs) on each day. Figure $\underline{5}$ shows the objects (176 days) plotted in a plane defined by three components. Two main clusters of objects can be distinguished: A rather compact cluster in the right-hand portion of the figure contains the majority of days (mainly from end of April until September). Since the variables that point toward certain objects are more important for those objects, it is obvious that these were the hot, cloudless, sunny days with light winds, higher atmospheric pressure (stagnant anticyclonic conditions), and consequently higher ozone concentrations. Thin cluster in the left portion of Fig. $\underline{5}$ contains the days, which are less frequent. It can clearly be seen that these days (mostly the first part of October) and lower ozone concentrations were supported by mostly cyclonic conditions (i.e., substantial cloud cover, as well as rainy, windy weather). It has been proven that PCA can be a useful and effective tool for researching voluminous sets of data such as ozone and meteorological data. Its application helped to visualize two distinct clusters with different ozone concentrations as well as dominant relationships existing in measured data.

\section{Conclusion}

Although Mali Lošinj is during summer period under heavier traffic load, the values of the two photochemical pollution indicators indicate low photochemical pollution, which is a consequence of anthropogenic factors, not just the local emissions. The values of AOT40 cumulative index show that there is a possibility of ozone injury to vegetation, but in regard to the value for the protection of human health, ozone concentrations are below the limits given by the EU Directive and Croatian law. The results of PCA revealed underlying relationships among $\mathrm{O}_{3}$ concentrations and meteorological data and showed that higher ozone concentrations are associated with slow-moving high pressure weather systems that result in sunny, moist, cloudless conditions and with typically light wind and air masses advected from Adriatic Sea. PCA proved to be a useful and effective tool for analysing voluminous sets of data such ozone and meteorological data.

Specific factors that contribute to the relatively moderate $\mathrm{O}_{3}$ levels observed in the area are certainly lack of industry and its remote location with effective ventilation conditions.

Further permanent studies are certainly needed to determine anthropogenic influences and transport of pollution as well as ozone injury on vegetation.

\section{Acknowledgment}

The authors acknowledge the Ministry of Science, Education and Sports of the Republic of Croatia for financial support, grant numbers 0098030 and 0982915-2947. We also thank the Croatian Meteorological and Hydrological Service for providing us with the meteorological data.

\section{References}

Abdul-Wahab SA, Bakheit CS, Al-Alawi SM (2005) Principal component and multiple regression analysis in modelling of ground-level ozone and factors affecting its concentrations. Environmental Modelling \& Software 20(10):1263-1271 $\underline{\text { rossRef }}$ 
Adame JA, Lozano A, Bolívar JP, De la Morena BA, Contreras J, Godoy F (2008) Behavior, distribution and variability of surface ozone at an arid region in the south of Iberian Peninsula (Seville, Spain). Chemosphere 70(5):841-849 CrossRef

Alebić-Juretić A (2011) Ozone levels in the Rijeka Bay area, Northern Adriatic, Croatia, 1999-2007. Int J Remote Sens 33(2):335-345. doi:10.1080/01431161.2010.490246 CrossRef

Ashmore MR (2005) Assessing the future global impacts of ozone on vegetation. Plant Cell Environ 28(8):949-964CrossRef

Banja M, Papanastasiou DK, Poupkou A, Melas D (2012) Development of a short-term ozone prediction tool in Tirana area based on meteorological variables. Atmos Pollut Res 3:32-38

Baumgarten M, Huber C, Bueker P, Emberson L, Dietrich H-P, Nunn AJ, Heerdt C, Beudert B, Matyssek R (2009) Are Bavarian Forests (southern Germany) at risk from ground-level ozone? Assessment using exposure and flux based ozone indices. Environ Pollut 157(7):2091-2107. doi:10.1016/j.envpol.2009.02.012 CrossRef

Božić M, Ivan K, Darko R (2006) Traffic counting on the roadways of Croatia in 2005digest. Zagreb (in Croatian)

Bytnerowicz A, Omasa K, Paoletti E (2007) Integrated effects of air pollution and climate change on forests: a northern hemisphere perspective. Environ Pollut 147(3):438-445. doi:10. 1016/j.envpol.2006.08.028 CrossRef

Cape JN (2008) Surface ozone concentrations and ecosystem health: past trends and a guide to future projections. Sci Total Environ 400(1-3):257-269. doi:10.1016/j.scitotenv.2008.06. $\underline{025} \underline{\text { CrossRef }}$

Chen R, Chu C, Tan J, Cao J, Song W, Xu X, Jiang C, Ma W, Yang C, Chen B, Gui Y, Kan H (2010) Ambient air pollution and hospital admission in Shanghai, China. J Hazard Mater 181(1-3):234-240. doi:10.1016/j.jhazmat.2010.05.002 CrossRef

Cieslik SA (2004) Ozone uptake by various surface types: a comparison between dose and exposure. Atmos Environ 38(15):2409-2420. doi:10.1016/j.atmosenv.2003.10.063 CrossRef

Cvitaš T, Furger M, Girgzdiene R, Haszpra L, Kezele N, Klasinc L, Planinsek A, Pompe M, Prevot ASH, Scheel HE, Schuepbach E (2004) Spectral analysis of boundary layer ozone data from the EUROTRAC TOR network. J Geophys Res-Atmos 109(D02302):doi:10.1029/ 2003jd003727

Directive 2002/3/EC of the European Parliament and of the Council relating to ozone in ambient air (12 February 2002). Official Journal of the European Communities, vol L 67

Directive 2008/50/EC of the European Parliament and of the Council on ambient air quality and cleaner air for Europe (21 May 2008). Official Journal of the European Union, vol L 152

Dueñas C, Fernández MC, Cañete S, Carretero J, Liger E (2002) Assessment of ozone variations and meteorological effects in an urban area in the Mediterranean Coast. Sci Total Environ 299(1-3):97-113

Even-Paz Z, Efron D (2003) Determination of solar ultraviolet dose in the Dead Sea treatment of psoriasis. Israel Med Assoc J 5:87-88

Ferretti M, Bussotti F, Calatayud V, Sanz M-J, Schaub M, Kraeuchi N, Petriccione B, Sanchez-Pena G, Ulrich E (2007) Ozone and forests in South-Western Europe. Environ Pollut 145(3):617-619. doi:10.1016/j.envpol.2006.02.026 CrossRef

Gvozdić V, Kovač-Andrić E, Brana J (2011) Influence of meteorological factors $\mathrm{NO}_{2}, \mathrm{SO}_{2}$, $\mathrm{CO}$ and $\mathrm{PM}_{10}$ on the voncentration of $\mathrm{O}_{3}$ in the urban atmosphere of Eastern Croatia. Environ Model Assess 16(5):491-501. doi:10.1007/s10666-011-9256-4 CrossRef

Kalabokas PD, Mihalopoulos N, Ellul R, Kleanthous S, Repapis CC (2008) An investigation of the meteorological and photochemical factors influencing the background rural and marine surface ozone levels in the Central and Eastern Mediterranean. Atmos Environ 42(34):78947906. doi:10.106/j.atmosenv.2008.07.009 $\underline{\text { CrossRef }}$ 
Kalabokas PD, Repapis CC (2004) A climatological study of rural surface ozone in central Greece. Atmos Chem Phys 4(4):1139-1147. doi:10.5194/acp-4-1139-2004 CrossRef

Kalabokas PD, Volz-Thomas A, Brioude J, Thouret V, Cammas JP, Repapis CC (2007) Vertical ozone measurements in the troposphere over the Eastern Mediterranean and comparison with Central Europe. Atmos Chem Phys Discuss 7(1):2249-2274. doi: $\underline{10.5194 /}$ acpd-7-2249-2007 CrossRef

Klasinc L, Cvitaš T, McGlynn SP, Hu M, Tang XY, Zhang YH (2011) Photochemical pollution indicators in the subtropics. Croat Chem Acta 84(1):11-16. doi: $\underline{10.5562 / \text { cca1807 }}$ $\underline{\text { CrossRef }}$

Klasinc L, Kezele N, Pompe M, McGlynn SP (2008) Trends, distribution and frequency analysis of ozone data from three monitoring stations in Baton Rouge, Louisiana for the years 1995 to 2005. Croat Chem Acta 81(2):311-318

Kley D, Geiss H, Mohnen VA (1994) Tropospheric ozone at elevated sites and precursor emissions in the United States and Europe. Atmos Environ 28:149-158. doi:10.1016/13522310(94)90030-2 CrossRef

Kovač-Andrić E, Šorgo G, Kezele N, Cvitaš T, Klasinc L (2010) Photochemical pollution indicators-an analysis of 12 European monitoring stations. Environ Monit Assess 165(14):577-583. doi:10.1007/s10661-009-0969-7 CrossRef

Kovač-Andrić E, Brana J, Gvozdić V (2009) Impact of meteorological factors on ozone concentrations modelled by time series analysis and multivariate statistical methods. Ecol Inf 4(2):117-122CrossRef

Kunst AE, Groenhof F, Anderson O, Borgan JK, Costa G, Desplanques G, Filakti H, Giraldes MD, Faggiano F, Harding S, Junker C, Martikainen P, Minder C, Nolan B, Pagnanelli F, Regidor E, Vagero D, Valkonen T, Mackenbach JP (1999) Occupational class and ischemic heart disease mortality in the United States and 11 European countries. Am J Public Health 89(1):47-53 CrossRef

Lengyel A, Héberger K, Paksy L, Bánhidi O, Rajkó R (2004) Prediction of ozone concentration in ambient air using multivariate methods. Chemosphere 57(8):889896CrossRef

Mills G, Pleijel H, Braun S, Büker P, Bermejo V, Calvo E, Danielsson H, Emberson L, Fernández IG, Grünhage L, Harmens H, Hayes F, Karlsson P-E, Simpson D (2011) New stomatal flux-based critical levels for ozone effects on vegetation. Atmos Environ 45(28):5064-5068CrossRef

Moosa Y, Esterhyse DJ (2010) Heliotherapy: a South African perspective. S Afr Med J 100:728-733

Notario A, Bravo I, Adame JA, Diaz-de-Mera Y, Aranda A, Rodriguez A, Dodriguez D (2012) Behavior and variability of local and regional oxidant levels $(\mathrm{OX}=\mathrm{O}(3)+\mathrm{NO}(2))$ measured in a polluted area in central-southern of Iberian. Environ Sci Pollut Res 20:188200. doi:10.1007/s11356-012-09741 CrossRef

Paoletti E (2009) Ozone and urban forests in Italy. Environ Pollut 157(5):1506-1512CrossRef Prtenjak MT, Jeričević A, Nitis T, Alebić-Juretić A, Bencetić Klaić Z (2009) Atmospheric boundary layer characteristics during high ozone concentrations in the Rijeka Bay area. In: Kungolos A, Aravossis K, Karagiannidis A, Samaras P (eds)Proceedings of the Second International Conference on Environmental Management, Engineering, Planning and Economics (CEMEPE 09) \& SECOTOX Conference. University of Thessaly and National Technical University of Athens, Athens, 1177-1182

Sánchez-Lorenzo A, Calbo J, Martin-Vide J (2008) Spatial and temporal trends in sunshine duration over Western Europe (1938-2004). J Clim 21:6089-6098. doi:10.1175/ 2008JCLI2442.1 CrossRef 
Schürmann GJ, Algieri A, Hedgecock IM, Manna G, Pirrone N, Sprovieri F (2009) Modelling local and synoptic scale influences on ozone concentrations in a topographically complex region of Southern Italy. Atmos Environ 43:4424-4434. doi:10.1016/j.atmosenv.2009.06.017 $\underline{\text { CrossRef }}$

Shutters ST, Balling RC Jr (2006) Weekly periodicity of environmental variables in Phoenix, Arizona. Atmos Environ 40(2):304-310 CrossRef

Stasić A, Batinac T, Komadina S (2004) Heliomarinotherapy in psoriasis. Acta Dermatovenerol Croat 12:51-54

Statheropoulos M, Vassiliadis N, Pappa A (1998) Principal component and canonical correlation analysis for examining air pollution and meteorological data. Atmos Environ 32(6):1087-1095 CrossRef

Stedman JR (2004) The predicted number of air pollution related deaths in the UK during the August 2003 heatwave. Atmos Environ 38(8):1087-1090. doi:10.1016/j.atmosenv.2003.11. $\underline{011}$ CrossRef

Velchev K, Cavalli F, Hjorth J, Marmer E, Vignati E, Dentener F, Raes F (2011) Ozone over the Western Mediterranean Sea - results from two years of shipborne measurements. Atmos Chem Phys 11(2):675-688. doi:10.5194/acp-11-675-2011 CrossRef

Wittig VE, Ainsworth EA, Naidu SL, Karnosky DF, Long SP (2009) Quantifying the impact of current and future tropospheric ozone on tree biomass, growth, physiology and biochemistry: a quantitative meta-analysis. Global Change Biol 15(2):396-424. doi:10.1111/j. 1365-2486.2008.01774.x CrossRef 